\title{
ANALISIS FAKTOR-FAKTOR PENGAMBILAN KEPUTUSAN PEMBELIAN KOSMETIK BERLABEL HALAL Di KOTA BOGOR
}

\author{
Oleh: \\ Retno Indraswari ${ }^{1}$ \\ Lindawati Kartika ${ }^{2}$ \\ Stevia Septiani ${ }^{3}$ \\ Departemen Manajemen, Fakultas Ekonomi dan Manajemen \\ Institut Pertanian Bogor \\ Email : \\ indraswariretno@gmail.com
}

\begin{abstract}
ABSTRAK
Seiring dengan meningkatnya pertumbuhan industri kosmetik di Indonesia, kesadaran konsumen akan jaminan produk kosmetik yang halal juga meningkat. Fenomena tersebut menyebabkan pembelian kosmetik halal di Indonesia juga meningkat. Tujuan diadakannya penelitian ini adalah untuk: (1) mengidentifikasi karakteristik responden, (2) menganalisis proses keputusan pembelian, dan (3) menganalisis faktor-faktor keputusan pembelian produk kosmetik berlabel halal di Kota Bogor. Metode penarikan sampel yang digunakan adalah non probabilitysampling dengan teknik snowball sampling. Analisis dilakukan dengan analisis deskriptif, analisis faktor, analisis crosstab, dan Net Promoter Score (NPS). Berdasarkan hasil penelitian didapatkan tiga kelompok faktor baru yang membentuk keputusan pembelian kosmetik berlabel halal yaitu faktor individu, konsep diri dan sosial-budaya. Sebanyak 37\% responden cenderung merekomendasikan produk kosmetik yang digunakannya kepada orang lain.
\end{abstract}

Kata Kunci: analisis faktor, keputusan pembelian, kosmetik, label halal

\begin{abstract}
Along with the rising growth of the cosmetics industry in Indonesia, the awareness of using halal cosmetics product also goes in the same parallel. That case leads to the increasing of halal cosmetic's purchasing in Indonesia. The purpose of this study is to identify the characteristics of respondents, analyzing the process of product purchase decision, and analyze the purchase decision factors of halal labeled cosmetics in Bogor. The sampling method used is nonprobability sampling with snowball sampling technique. The analysis used the descriptive analysis, factor analysis, crosstab analysis, and Net Promoter Score (NPS). The result shows that there were three new factors which are related to
\end{abstract}


purchase decision e.g. personal, self-concept and social-culture factor. The NPS analysis shows that $37 \%$ of respondents are tended to recommend cosmetics product they use to other people.

Keywords: factor analysis, purchasing decisions, cosmetic, halal label

\section{A. PENDAHULUAN}

Tampil menarik adalah dambaan setiap wanita di mana pun dan kapan pun. Untuk itu banyak cara dilakukan untuk mendapatkan tampilan yang diinginkan. Salah satu yang menjadi pilihan adalah dengan memakai produk kosmetik. Penggunaan kosmetik di zaman sekarang ini hampir menjadi kebutuhan primer bagi wanita. Menurut Survey Bizteka (2015), pertumbuhan pasar industri kosmetik di Indonesia rata-rata mencapai $9.67 \%$ per tahun dan terus meningkat selama enam tahun terakhir. Nilai penjualan industri kosmetik di Indonesia dapat dilihat pada Tabel 1 .

Tabel 1.

Nilai Penjualan Industri Kosmetik di Indonesia

\begin{tabular}{lrrrrrr}
\hline Keterangan & $\mathbf{2 0 1 0}$ & $\mathbf{2 0 1 1}$ & $\mathbf{2 0 1 2}$ & $\mathbf{2 0 1 3}$ & $\mathbf{2 0 1 4}$ & $\mathbf{2 0 1 5}$ \\
\hline Nilai pasar (Rp) (triliun) & 8.90 & 8.50 & 9.76 & 11.20 & 12.88 & 13.94 \\
Pertumbuhan (\%) & - & -4.49 & 14.82 & 14.75 & 14.95 & 8.30 \\
\hline Sumber : Survey Bizteka (2015) & & & & &
\end{tabular}

Berdasarkan data pada Tabel 1, industri kosmetik Indonesia selama enam tahun terakhir terus mengalami pertumbuhan. Center for Middle-Class Consumer Studies (2013) menyebutkan pada sepuluh tahun terakhir ini, terjadi peningkatan perkembangan gaya hidup yang berorientasi modern dan islami di Indonesia. Perkembangan gaya hidup tersebut dapat dilihat dari beberapa fenomena seperti masyarakat semakin kritis dalam menilai kehalalan produk yang akan dikonsumsi, berkembangnya lembaga keuangan berbasis syariah, pertumbuhan budaya bernuansa Islam, berkembangnya pemakaian busana hijab, munculnya hotel syariah, peningkatan frekuensi kunjungan ibadah haji dan umrah, pertumbuhan industri kosmetik halal dan meningkatnya kewirausahaan muslim. Konsumen lebih selektif dan teliti dalam melakukan pembelian produk yang akan digunakannya. Berbagai produk halal yang beredar yang banyak digunakan konsumen, salah satunya adalah kosmetik.

Berbagai produk halal yang beredar yang banyak digunakan konsumen, salah satunya adalah kosmetik. Kosmetik halal merupakan produk yang digunakan untuk membersihkan, menambah daya tarik, melindungi, memperbaiki bagian luar tubuh dan tidak termasuk dalam golongan obat yang tidak mengandung bahan yang diharamkan. Kehalalan kosmetik di Indonesia, diuji oleh Lembaga Pengkajian Pangan, Obat-obatan, dan Kosmetika Majelis Ulama Indonesia atau yang disebut LPPOM MUI. Kosmetik yang telah lulus uji kehalalannya akan mendapat sertifikat kehalalan dan diizinkan mencantumkan label halal di produknya. 
Kosmetik berlabel halal memberi keuntungan bagi berbagai pihak, baik produsen maupun konsumen. Label halal melindungi produsen dari tuntutan adanya bahan dan proses yang tidak halal pada produk tersebut, melindungi konsumen dari keraguan atas produk tersebut dan memberi nilai tambah rasa aman dan kepastian kehalalan produk tersebut.

Belum semua produk kosmetik di Indonesia tersertifikasi halal oleh LPPOM MUI. Menurut Persatuan Perusahaan Kosmetika Indonesia (PERKOSMI) tahun 2016, dari 500 perusahaan kosmetik hanya 70 perusahaan yang bersertifikasi halal. Walaupun demikian, nilai pasar kosmetik terus meningkat setiap tahunnya yang dapat dilihat pada Gambar 1.

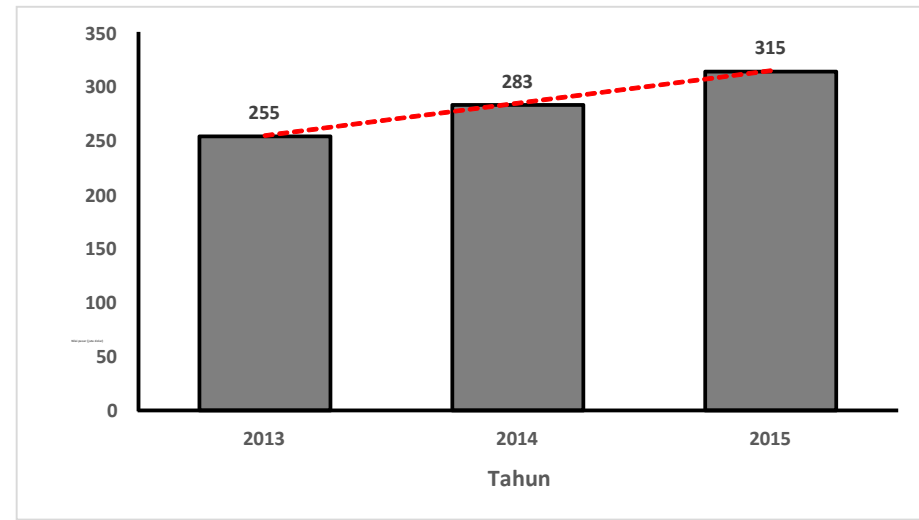

Sumber : Tirto (2016)

Gambar 1.

Nilai Pasar Kosmetik Halal Indonesia

Gambar 1 menunjukkan nilai pasar kosmetik yang terus meningkat dari tahun 2013 hingga 2015. Pada tahun 2017 DPRD Kota Bogor mewacanakan membuat 23 Peraturan Daerah. Salah satu dari Peraturan Daerah tersebut tentang perencanaan Kota Bogor sebagai Kota Halal (www.tibunnews.com). Tujuan dibentuknya Perda tersebut adalah untuk menjamin kebutuhan para konsumen akan produk-produk halal. Dengan dibentuknya perda tersebut diharapkan Kota Bogor dapat menjadi pionir kota halal pertama di Indonesia. Oleh karena itu, penelitian tentang Analisis Faktor-Faktor Pengambilan Keputusan Pembelian Kosmetik Berlabel Halal di Bogor penting untuk dilakukan. Berdasarkan rumusan masalah di atas, maka penelitian ini bertujuan untuk:

1. Mengetahui karateristik responden yang menggunakan kosmetik berlabel halal.

2. Menganalisis proses keputusan pembelian responden terhadap kosmetik berlabel halal.

3. Menganalisis faktor-faktor pengambilan keputusan pembelian responden terhadap kosmetik halal. 


\section{B. KAJIAN PUSTAKA}

\section{Kosmetik}

Menurut Badan Pengawas Obat dan Makanan (BPOM) Republik Indonesia tahun 2011, kosmetik adalah setiap bahan atau sediaan yang dimaksudkan untuk digunakan pada bagian luar tubuh manusia (epidermis, rambut, kuku, bibir, dan organ genital bagian luar), atau gigi dan membran mukosa mulut, terutama untuk membersihkan, mewangikan, dan mengubah penampilan, dan/atau memperbaiki bau badan atau melindungi atau memelihara tubuh pada kondisi baik.

\section{Labelisasi Halal}

Berdasarkan Peraturan Menteri Perdagangan No.67/M-DAG/PER/11/2013 label adalah setiap keterangan mengenai barang yang berbentuk gambar, tulisan, kombinasi keduanya atau bentuk lain yang memuat informasi tentang barang dan keterangan pelaku usaha serta informasi lainnya sesuai dengan ketentuan peraturan perundang-undangan yang berlaku.

Menurut LPPOM-MUI, sertifikat halal adalah fatwa tertulis yang dikeluarkan oleh MUI yang menyatakan kehalalan suatu produk yang merupakan keputusan sidang Komisi Fatwa MUI berdasarkan proses audit yang dilakukan oleh LPPOM MUI. Menurut UU Republik Indonesia nomor 33 tahun 2014, produk halal adalah produk yang telah dinyatakan halal sesuai dengan syariat Islam.

Labelisasi halal adalah perizinan pemasangan keterangan "HALAL" pada kemasan produk yang dikeluarkan oleh Badan POM didasarkan rekomendasi MUI dalam bentuk sertifikat halal MUI. Sertifikat halal MUI dikeluarkan oleh MUI berdasarkan hasil pemeriksaan LPPOM MUI terhadap produk yang bersangkutan. Produk halal adalah produk yang memenuhi syarat kehalalan sesuai dengan syariat Islam.

\section{Perilaku Konsumen}

Menurut Schiffman dan Kanuk (2011) istilah perilaku konsumen diartikan sebagai perilaku yang diperlihatkan konsumen dalam mencari, membeli, menggunakan, mengevaluasi, dan menghabiskan produk dan jasa yang mereka harapkan akan memuaskan kebutuhan mereka. Sedangkan Engel, Blackwell, dan Miniard (2011) mengartikan perilaku konsumen sebagai tindakan yang langsung terlibat dalam mendapatkan, mengonsumsi, dan menghabiskan produk dan jasa, termasuk proses keputusan yang mendahului dan mengikuti tindakan ini. Menurut Kotler dan Armstrong (2008) perilaku konsumen dipengaruhi oleh beberapa faktor, yaitu sebagai berikut:

\section{Faktor Budaya}

Budaya adalah determinan dasar keinginan dan perilaku seseorang. Kelas budaya, sub-budaya, dan sosial sangat mempengaruhi perilaku pembelian konsumen. 


\section{Faktor Sosial}

Kelompok referensi, keluarga, serta peran sosial dan status adalah faktorfaktor sosial yang mempengaruhi perilaku konsumen. Kelompok referensi adalah semua kelompok yang mempunyai pengaruh langsung atau tidak langsung terhadap sikap atau perilaku seseorang. Keluarga adalah organisasi pembelian konsumen yang paling penting dalam masyarakat, dan anggota keluarga mempresentasikan kelompok referensi utama yang paling berpengaruh.

\section{Faktor Pribadi}

Faktor pribadi meliputi usia dan tahap dalam siklus hidup pembeli, pekerjaan dan keadaan ekonomi, kepribadian dan konsep diri, serta gaya hidup dan nilai. Sebagian besar dari karakteristik ini mempunyai dampak yang sangat langsung terhadap perilaku konsumen.

\section{Faktor Psikologis}

Faktor psikologis utama yang mempengaruhi perilaku konsumen adalah motivasi, persepsi, pembelajaran, serta keyakinan dan sikap. Motif (motive) atau dorongan, adalah kebutuhan dengan tekanan kuat yang mengarahkan seseorang mencari kepuasan. Orang yang termotivasi siap beraksi. Cara orang tersebut bertindak dipengaruhi oleh persepsi dirinya tentang sebuah situasi. Ketika orang bertindak, mereka belajar. Melalui pelaksanaan dan pembelajaran, seseorang mendapatkan keyakinan dan sikap. Model respons rangsangan adalah titik awal untuk memahami perilaku konsumen. Rangsangan pemasaran dan lingkungan memasuki kesadaran konsumen, dan sekelompok proses psikologis digabungkan dengan karakteristik konsumen tertentu menghasilkan proses pengambilan keputusan dan keputusan akhir konsumen.

\section{Keputusan Pembelian}

Menurut Kotler dan Keller (2009) sebelum melakukan pembelian konsumen melalui lima tahap keputusan pembelian yaitu pengenalan masalah, pencarian informasi, evaluasi alternatif, keputusan pembelian dan perilaku pascapembelian.Konsumen tidak selalu melalui lima tahap pembelian produk itu seluruhnya. Mereka mungkin melewatkan atau membalik beberapa tahap. Tahapan pembelian konsumen yaitu sebagai berikut:

1. Pengenalan Masalah

Proses pembelian dimulai ketika pembeli menyadari suatu masalah atau kebutuhan yang dipicu oleh rangsangan internal atau eksternal. Dengan rangsangan internal, salah satu dari kebutuhan normal seseorang naik ke tingkat maksimum dan menjadi dorongan; atau kebutuhan bisa timbul akibat rangsangan eksternal.

2. Pencarian Informasi 
Sumber informasi utama konsumen yaitu terdiri dari empat kelompok: pribadi, komersial, publik, dan eksperimental. Jumlah dan pengaruh relatif dari sumber informasi bervariasi dengan kategori produk dan karakteristik pembeli. Secara umum, konsumen menerima informasi terpenting dari sebuah produk dari komersial, yaitu sumber yang didominasi pemasar.

3. Evaluasi Alternatif

Proses evaluasi produk dimulai dengan pertama: konsumen yang berusaha memuaskan sebuah kebutuhan. Kedua, konsumen mencari manfaat tertentu dari solusi produk. Ketiga, konsumen melihat masing-masing produk sebagai sekelompok atribut dengan berbagai kemampuan untuk menghantarkan manfaat yang diperlukan untuk memuaskan kebutuhan ini. Konsumen akan memberikan perhatian terbesar pada atribut yang menghantarkan manfaat yang memenuhi kebutuhan.

4. Keputusan Pembelian

Dalam tahap keputusan pembelian terdapat model kompensatoris dan non kompensatoris. Model kompensatoris adalah hal-hal yang dianggap baik untuk sebuah produk dapat membantu menutup hal-hal yang dianggap buruk. Sedanngkan model nonkompensatoris adalah dimana pertimbangan atribut positif dan negatif tidak selalu saling mengurangi.

5. Perilaku Pascapembelian

Kepuasan merupakan fungsi kedekatan antara harapan dan kinerja anggapan produk. Jika kinerja tidak memenuhi harapan, konsumen kecewa; jika memenuhi harapan, konsumen puas, jika melebihi harapan, konsumen sangat puas. Semakin besar kesenjangan antara harapan dan kinerja, semakin besar ketidakpuasan yang terjadi. Perasaan ini menentukan apakah pelanggan membeli produk kembali.

\section{METODE PENELITIAN}

\section{Metode Penarikan Sampel}

Penelitian ini menggunakan metode survei, dengan teknik pengumpulan data kuesioner. Populasi penelitian adalah penduduk Kota Bogor berjenis kelamin perempuan dengan usia minimal 15 tahun. Metode pemilihan sampel yang digunakan adalah metode nonprobability sampling dengan teknik snowball sampling.

Berdasarkan data BPS 2015, penduduk wanita yang bekerja di Kota Bogor adalah sebanyak 107776 (BPS 2015). Jumlah sampel diambilsebanyak 100 orang.

$$
n=\frac{107776}{\left(1+107776(0.1)^{2}\right)}=99.91 \approx 100
$$




\section{Metode Pengolahan dan Analisis Data}

Metode analisis data yang digunakan dalam penelitian ini adalah metode analisis deskriptif, analisis crosstab dengan chi-square, analisis faktor dan Net Promoter Score (NPS). Sebelum data kuesioner dianalisis lebih lanjut maka dilakukan uji validitas dan uji reliabilitas.

\section{Analisis Deskriptif}

Menurut Riduwan dan Sunarto (2011), analisis deskriptif adalah analisis yang menggambarkan suatu data yang dibuat, baik sendiri maupun secara kelompok. Dalam penelitian ini, analisis deskriptif digunakan untuk data bersifat kualitatif yang diperoleh melalui pengisian kuesioner oleh responden. Analisis deskriptif yang digunakan dalam penelitian ini adalah modus. Analisis deskriptif mengidentifikasi karakteristik konsumen yang selanjutnya dibuat ke dalam bentuk tabulasi.

\section{Analisis Faktor}

Menurut Widarjono (2015), analisis faktor merupakan cara untuk mencari atau mendapatkan sejumlah variabel indikator yang mampu memaksimumkan korelasi antara variabel indikator. Ada dua jenis analisis faktor, yaitu analisis faktor eksploratori (Exploratory Factor Analysis = EFA) dan analisis faktor konfirmatori (Confirmatory Factor Analysis = CFA). Pada penelitian ini digunakan analisis faktor eksploratori yaitu pengujian dilakukan dengan mencari sejumlah indikator untuk membentuk faktor umum (common factor) tanpa ada landasan teori sebelumnya. Dengan kata lain analisis faktor eksploratori merupakan sebuah metode untuk membangun teori (theory building). Langkahlangkah dalam analisis faktor adalah sebagai berikut :

1) Menghitung korelasi antara indikator yang diobservasi

Di dalam melakukan analisis faktor, keputusan pertama yang harus diambil oleh peneliti adalah menganalisis apakah data yang ada cukup memenuhi syarat di dalam analisis faktor. Beberapa ukuran dapat digunakan untuk syarat kecukupan data sebagai rule of thumb, pada penelitian ini korelasi indikator dihitung dengan metode Kaiser-Meyer $\operatorname{Olkin}(K M O)$.

2) Ekstraksi faktor

Ekstraksi faktor adalah metode untuk mereduksi data dari beberapa indikator untuk menghasilkan faktor yang lebih sedikit yang mampu menjelaskan korelasi antara indikator yang diobservasi. Dalam penelitian ekstraksi faktor menggunakan Principal Components Analysis.

3) Rotasi faktor

Rotasi faktor diperlukan jika metode ekstraksi faktor belum menghasilkan komponen faktor utama yang jelas. Ada beberapa 
metode yang bisa digunakan, rotasi faktor yang digunakan untuk penelitian ini adalah Varimax Method.

\section{Analisis Crosstab dengan Uji Chi-Square}

Tabel Tabulasi silang (Crosstabulation Tables), atau biasa disingkat tabel silang (Crosstab), merupakan alat statistik yang dapat digunakan untuk melihat hubungan dari kombinasi dua atau lebih variabel (Simamora 2005). Wahyono (2006) mengemukakan bahwa analisis crosstabs merupakan analisa yang masuk dalam kategori statistik di mana menampilkan tabulasi silang atau table kontingensi yang menunjukkan suatu distribusi bersama dan pengujian hubungan antara dua variable atau lebih. Sedangkan uji Chi-Square atau yang sering disebut juga Chi kuadrat digunakan untuk menguji keselarasan, dimana pengujian dilakukan untuk memeriksa kebergantungan dan homogenitas dari suatu data. Uji Chi-Square akan mengamati secara lebih detail tentang ada dan tidaknya hubungan antar variabel.

\section{4. $\quad$ Net Promoter Score (NPS)}

Menurut Reichheld (2011) NPS didasari oleh pengamatan yang membagi konsumen menjadi tiga kelompok dengan masing-masing pola perilaku. Promoter adalah konsumen yang antusias dan loyal membeli produk dan mendorong temantemannya untuk mencoba. Passive adalah konsumen yang puas tetapi tidak antusias untuk mendorong orang lain untuk mencoba produk yang dibelinya, konsumen passive dapat dengan mudah tergoda oleh produk lain atau kompetitor. Detractor adalah konsumen yang merasa tidak puas dan tidak akan merekomendasikan produk yang dibeli kepada orang lain. Ilustrasi Net Promoter Score dapat dilihat pada Gambar 2.

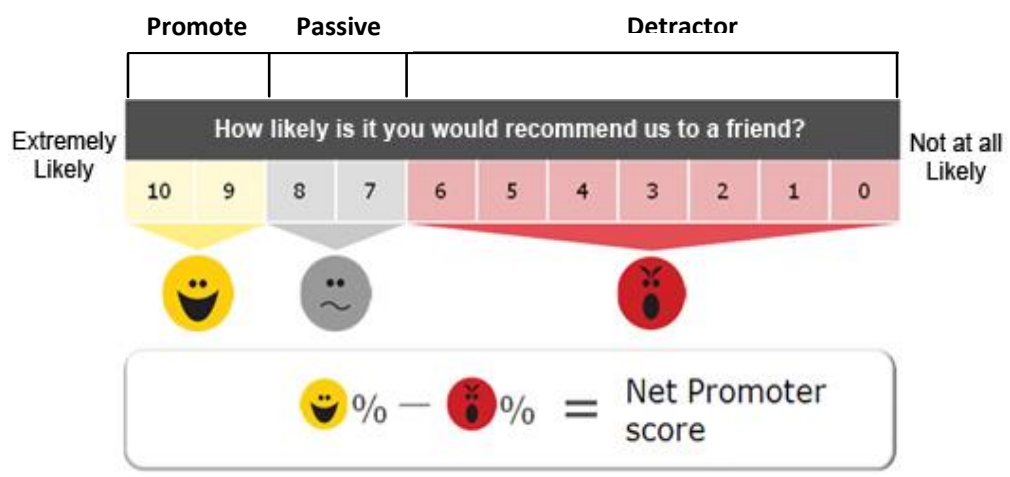

Sumber : Reichheld (2011)

Gambar 2.

Net Promoter Score (NPS)

Berdasarkan Gambar 2 diketahui bahwa skala kelompok promoter adalah konsumen yang memberikan nilai 9 atau 10, passive adalah konsumen yang 
memberikan nilai 7 atau 8 , dan detractor adalah konsumen yang memberikan nilai 0 sampai 6. Dalam penelitian ini responden dibagi menjadi 3 kategori:

1) Detractor: Responden yang menyatakan tidak akan merekomendasikan kosmetik berlabel "halal"

2) Passive: Responden yang menyatakan "Jika diminta, akan merekomendasikan kosmetik berlabel halal"

3) Promoter: Responden yang menyatakan "Pasti akan merekomendasikan kosmetik berlabel halal"

\section{HASIL Dan PEMBAHASAN}

\section{Karakteristik Responden}

Berdasarkan hasil penelitian didapatkan karakteristik responden berdasarkan usia, pendidikan, pekerjaan, pendapatan, pengeluaran, dan frekuensi pembelian. Dalam penelitian ini mayoritas responden berusia 20 sampai 24 tahun dengan persentase sebesar $69 \%$. Berdasarkan pendidikan terakhir responden, mayoritas D3 dengan persentase $46 \%$. Mayoritas responden bekerja sebagai pegawai swasta dengan persentase $75 \%$. Berdasarkan pendapatan, mayoritas responden memiliki selang pendapatan Rp 3100000 - Rp 4000000 dengan persentase $37 \%$. Responden rata-rata menghabiskan Rp 101000 - Rp 200000 setiap bulan untuk membeli kosmetik. Sedangkan frekuensi pembelian kosmetik setiap tahunnya responden mayoritas melakukan 4 sampai 6 kali pembelian.

\section{Hasil Uji Validitas dan Reliabilitas}

Uji validitas dalam penelitian ini menggunakan metode korelasi Product Moment Pearson. Tingkat kepercayaan yang digunakan sebesar 90 persen yaitu $\alpha$ sebesar $0.10\left(\mathrm{r}_{\text {tabel }}=0.3061\right)$. Hasil uji validitas menunjukkan bahwa item dalam kuesioner valid. Hal tersebut dikarenakan $r_{\text {hitung }}>r_{\text {tabel }}$ yaitu antara $0.546-0.837$. Uji reliabilitas dilakukan dengan menggunakan metode Alpha Cronbach. Untuk menentukan apakah instrumen reliabel yaitu dengan menggunakan batasan 0.6 yaitu jika $\alpha_{\text {hitung }}>\alpha_{\text {Cronbach }}(0.6)$, maka indikator tersebut reliabel. Hasil uji reliabilitas menghasilkan nilai Cronbach Alpha sebesar 0.92, sehingga seluruh atribut item dalam kuesioner dapat dinyatakan reliabel.

\section{Pengetahuan Responden Terhadap Kosmetik Berlabel Halal}

\section{Merek Kosmetik yang Dipakai Responden}

Berdasarkan hasil penelitian terdapat 29 merek kosmetik yang biasa digunakan oleh responden. Berikut merek kosmetik dan jumlah responden yang menggunakannya dapat dilihat pada Tabel 2. 
Tabel 2.

Merek Kosmetik yang Digunakan Responden

\begin{tabular}{ccccclcc}
\hline No & $\begin{array}{c}\text { Merek } \\
\text { kosmetik }\end{array}$ & $\begin{array}{c}\text { Jumlah } \\
\text { responden }\end{array}$ & Persentase & No & $\begin{array}{c}\text { Merek } \\
\text { kosmetik }\end{array}$ & $\begin{array}{c}\text { Jumlah } \\
\text { responden }\end{array}$ & Persentase \\
\hline 1 & Wardah* & 89 & $23.54 \%$ & 16 & Mazaya* & 2 & $0.53 \%$ \\
2 & Maybelline & 42 & $11.11 \%$ & 17 & Erha & 2 & $0.53 \%$ \\
3 & Make Over* & 37 & $9.79 \%$ & 18 & Sr12 & 2 & $0.53 \%$ \\
4 & Purbasari* & 37 & $9.79 \%$ & 19 & Etude & 1 & $0.26 \%$ \\
5 & Emina* & 30 & $7.94 \%$ & 20 & Lancome & 1 & $0.26 \%$ \\
6 & Revlon & 24 & $6.35 \%$ & 21 & Marcks* & 1 & $0.26 \%$ \\
7 & NYX & 22 & $5.82 \%$ & 22 & The Saem & 1 & $0.26 \%$ \\
8 & Sariayu* & 18 & $4.76 \%$ & 23 & Bourjois & 1 & $0.26 \%$ \\
9 & Pixy* & 13 & $3.44 \%$ & 24 & LT PRO* & 1 & $0.26 \%$ \\
10 & Mustika Ratu* & 12 & $3.17 \%$ & 25 & Ertos & 1 & $0.26 \%$ \\
11 & Mineral & 11 & $2.91 \%$ & 26 & Cream & 1 & $0.26 \%$ \\
& Botanica* & & & & DiVa & & \\
12 & Silky Girl* & 10 & $2.65 \%$ & 27 & Everwhite & 1 & $0.26 \%$ \\
13 & La Tulipe & 9 & $2.38 \%$ & 28 & Viva* & 1 & $0.26 \%$ \\
14 & ZOYA* & 5 & $1.32 \%$ & 29 & Larissa & 1 & $0.26 \%$ \\
15 & Laneige & 2 & $0.53 \%$ & & & & \\
\hline S & & & & & & & \\
\hline
\end{tabular}

Sumber : Data diolah (2018)

Keterangan : * $=$ kosmetik bersertifikat halal

Tabel 2 menunjukkan merek-merek kosmetik yang terdiri dari merek lokal maupun luar negeri. Selanjutnya dari data di atas maka kosmetik dapat di kategorikan ke dalam kelompok kosmetik berlabel halal dan tidak berlabel halal. Kehalalan produk kosmetik tersebut didasarkan pada data Daftar Produk Halal LPPOM-MUI Desember 2017. Berdasarkan dua kategori tersebut didapatkan bahwa sebanyak $71 \%$ responden menggunakan produk kosmetik halal, dimana $26 \%$ nya menggunakan produk Wardah.

\section{Respon Responden tentang Bahan Non-Halal dalam Kosmetik}

Berdasarkan hasil penelitian, sebanyak $86 \%$ responden mengetahui komposisi bahan baku yang menyebabkan kosmetik tersebut diragukan kehalalannya, sedangkan sebanyak $14 \%$ lainnya tidak atau belum mengetahui. Selanjutnya, berdasarkan hasil kuesioner sebanyak 66\% responden mencari informasi mengenai kehalalan produk kosmetik sebelum memutuskan untuk membeli. Sedangkan sebanyak 34\% lainnya tidak mencari tahu informasi kehalalan produk kosmetik sebelum membeli. Informasi kehalalan berupa ada tidaknya label halal pada kemasan produk kosmetik atau status kehalalan yang dapat dilihat pada website LPPOM-MUI. Selanjutnya, untuk mendukung jawaban responden tentang bahan baku pada kosmetik halal, responden diminta untuk menyebutkan bahan baku non-halal dalam produk kosmetik. Jawaban responden terhadap bahan non-halal dapat dilihat pada Gambar 3 berikut. 


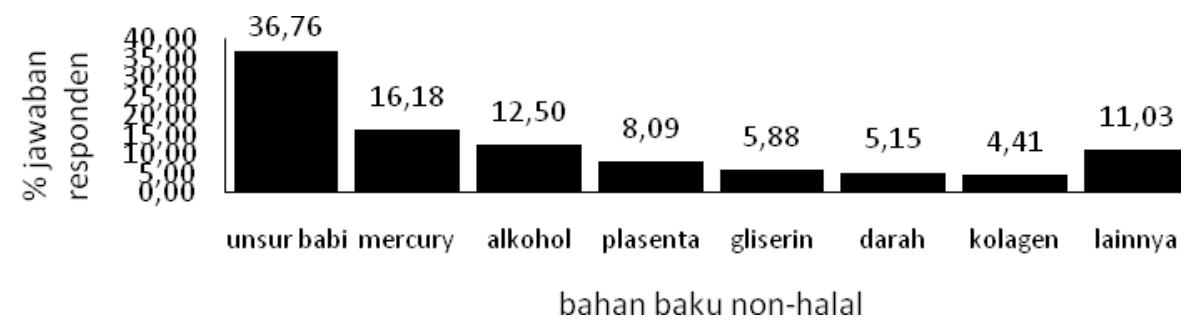

Gambar 3.

\section{Jawaban Responden tentang Bahan Non-Halal pada Kosmetik}

\section{Tanggapan Responden tentang Gambaran Kosmetik Berlabel Halal}

Berdasarkan jawaban responden terhadap gambaran tentang kosmetik berlabel halal maka jawaban tersebut dapat dikelompokkan ke dalam empat kelompok yaitu kosmetik berlabel halal adalah 1) kosmetik yang tidak mengandung bahan haram atau sesuai syariat Islam; 2) kosmetik berlabel halal aman untuk digunakan; 3) kosmetik berlabel halal bermanfaat atau memiliki citra yang baik; 4) kosmetik berlabel halal adalah kosmetik yang memiliki label halal pada kemasannya serta dipromosikan dengan menonjolkan kehalalannya. Tanggapan responden dapat dilihat pada Gambar 4.

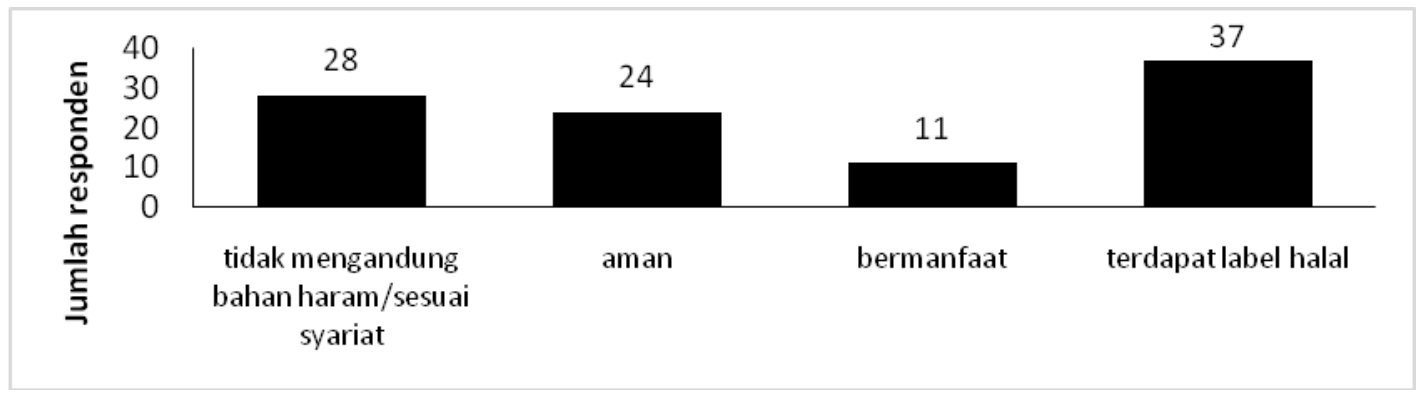

Gambar 4.

Tanggapan tentang Gambaran Kosmetik Berlabel Halal

Berdasarkan Gambar 4 diketahui bahwa sebagian besar responden menggambarkan kosmetik berlabel halal sebagai kosmetik yang memiliki logo atau keterangan halal pada kemasannya serta dipromosikan dengan menonjolkan kehalalan produknya. Hal ini menunjukkan kesadaran dan perhatian responden terhadap atribut produk kosmetik berlabel halal.

\section{Identifikasi Proses Pengambilan Keputusan Pembelian Kosmetik Berlabel Halal}

Dalam membeli suatu produk konsumen melalui tahap-tahap keputusan. Tahapan tersebut terdiri dari: pengenalan keputusan, pencarian informasi, evaluasi aternatif, keputusan pembelian, dan evalusai pasca pembelian. Berdasarkan hasil penelitian tahap-tahap keputusan pebelian responden terhadap kosmetik berlabel halal dapat dijabarkan dalam beberapa tabel berikut.

1. Pengenalan Kebutuhan 
Proses pembelian dimulai ketika responden menyadari suatu masalah atau kebutuhan yang dipicu oleh rangsangan internal atau eksternal. Pada penelitian ini proses pengenalan responden meliputi motivasi pembelian, faktor sosial, dan pertimbangan label halal saat melakukan pembelian kosmetik. Hasil proses pengenalan masalah dapat dilihat pada Tabel 3 .

Tabel 3.

Hasil Tahap Pengenalan Kebutuhan

\begin{tabular}{|c|c|c|}
\hline Pengenalan Kebutuhan & Keterangan & Jumlah (\%) \\
\hline \multirow[t]{5}{*}{ Motivasi } & Mutu sesuai & 59 \\
\hline & Harga & 18 \\
\hline & Dorongan promosi & 10 \\
\hline & Mudah diperoleh & 8 \\
\hline & Lainnya & 5 \\
\hline \multicolumn{2}{|l|}{ Subtotal } & 100 \\
\hline \multirow[t]{6}{*}{ Faktor sosial } & Teman & 46 \\
\hline & Model iklan & 15 \\
\hline & Rekan kerja & 13 \\
\hline & Keluarga & 9 \\
\hline & Sales representative & 5 \\
\hline & Lainnya & 12 \\
\hline \multicolumn{2}{|l|}{ Subtotal } & 100 \\
\hline \multirow[t]{2}{*}{ Label halal sebagai pertimbangan pembelian } & $\mathrm{Ya}$ & 83 \\
\hline & Tidak & 17 \\
\hline Subtotal & & 100 \\
\hline
\end{tabular}

Sumber : Data diolah (2018)

Berdasarkan Tabel 3, diketahui bahwa motivasi mayoritas responden membeli produk kosmetik berlabel halal adalah karena mutu yang sesuai yaitu sebanyak 59\%. Mutu pada produk kosmetik berlabel halal sesuai dengan yang diharapkan oleh responden, sehingga mendorong responden untuk melakukan pembelian. Pengaruh terbanyak dengan persentase sebesar $46 \%$ adalah teman, menunjukkan adanya peran Word of Mouth dalam pemasaran kosmetik halal.

Sebesar $83 \%$ responden menjawab bahwa label halal menjadi pertimbangan saat membeli produk kosmetik. Sedangkan, sebesar $17 \%$ lainnya menyatakan tidak mempertimbangkan label halal pada kosmetik sebelum membeli. Hal ini berarti menunjukkan bahwa label halal penting dicantumkan pada kemasan produk kosmetik yang telah bersertifikat halal.

\section{Pencarian Informasi}

Pada penelitian ini pencarian informasi meliputi pencarian informasi kehalalan produk, informasi pada kemasan dan sumber-sumber informasi produk kosmetik berlabel halal. Hasil proses pencarian informasi dapat dilihat pada Tabel 4. 
Tabel 4.

Hasil Tahap Pencarian Informasi

\begin{tabular}{lllc}
\hline Pencarian Informasi & \multicolumn{1}{c}{ Keterangan } & Jumlah (\%) \\
\hline Mencari tahu informasi kehalalan produk & Ya & 70 \\
& & Tidak & 30 \\
\hline & Subtotal & & 100 \\
\hline Informasi pada kemasan & & Komposisi bahan & 42 \\
& & Spesifikasi & 27 \\
& & Tanggal kadaluarsa & 25 \\
& & Cara pemakaian & 4 \\
& & Lainnya & 2 \\
\hline Sumber informasi & Subtotal & & 100 \\
& & Sumber komersial & 57 \\
& & Sumber pribadi & 19 \\
& & Sumber publik & 14 \\
& & Sumber pengalaman & 10 \\
\hline & Subtotal & & 100 \\
\hline
\end{tabular}

Sumber : Data diolah (2018)

Berdasarkan Tabel 4, didapatkan sebesar $70 \%$ responden mencari tahu informasi kehalalan produk kosmetik sebelum membeli. Sedangkan, 30\% lainnya membeli produk kosmetik tanpa terlebih dulu mencari informasi kehalalannya. Informasi yang paling diperhatikan pada kemasan kosmetik adalah komposisi bahan dengan persentase sebesar $42 \%$. Sumber informasi dimana responden pertama kali mengetahui kosmetik berlabel halal terbanyak adalah dari sumber komersil sebesar 57\%. Sumber komersial meliputi iklan, wiraniaga, website, kemasan dan televisi menjadi media paling efektif untuk memberikan informasi sekaligus mempromosikan kosmetik berlabel halal.

Selanjutnya responden menyebutkan merek produk kosmetik yang pertama kali muncul saat disebutkan kata kosmetik. Jawaban responden terhadap merek kosmetik oleh responden dapat dilihat pada Gambar 5.

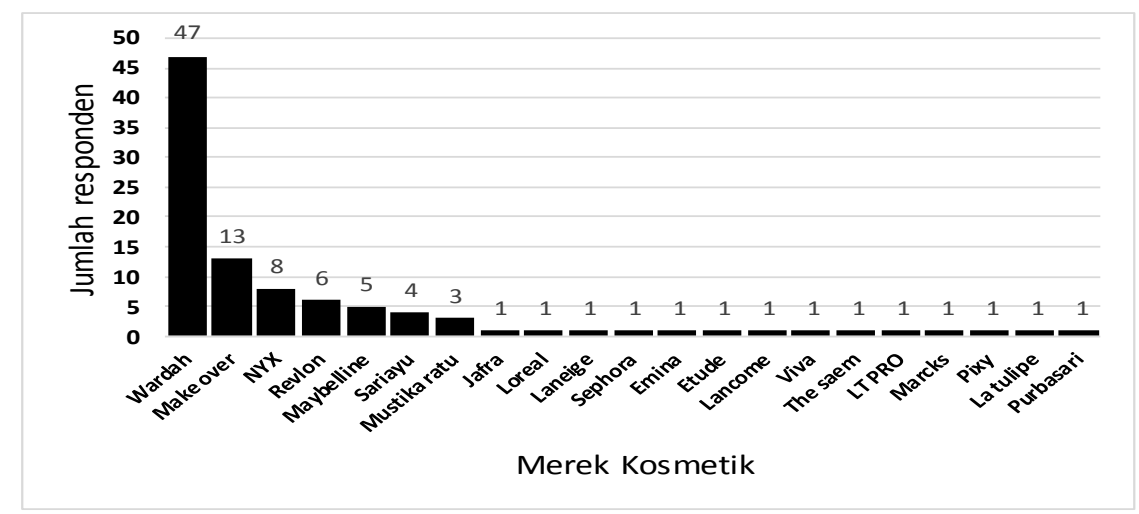

Sumber : Data diolah (2018)

Gambar 5.

Respon terhadap Merek Kosmetik 
Berdasarkan Gambar 5, terdapat beberapa merek kosmetik sebagai tanggapan dari responden tentang merek yang pertama kali muncul dalam pikiran saat disebutkan kata kosmetik. Jawaban terbanyak adalah merek kosmetik Wardah yaitu sebanyak 47, selanjutnya merek Make Over sebanyak 13, NYX sebanyak 8.

Selain diberikan pertanyaan tentang merek kosmetik, responden juga diberikan pertanyaan tentang merek produk kosmetik halal yang menjadi top of mind mereka. Selanjutnya tanggapan responden terhadap merek kosmetik halal dapat dilihat pada Gambar 6.

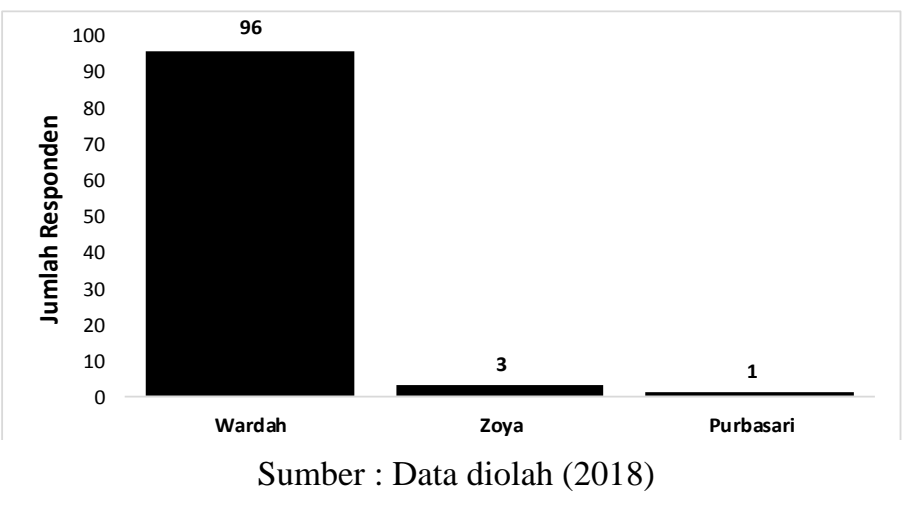

\section{Gambar 6. \\ Top of Mind kosmetik berlabel halal}

Berdasarkan grafik pada Gambar 6, terdapat tiga merek kosmetik sebagai jawab responden tentang merek kosmetik berlabel halal yang pertama kali muncul dalam pikiran. Jawaban terbanyak adalah merek kosmetik Wardah yaitu sebesar 96, merek Zoya sebanyak 3, dan merek Purbasari sebanyak 1.

\section{Evaluasi Alternatif}

Pada penelitian ini proses evaluasi alternatif meliputi dasar pertimbangan memilih kosmetik serta keyakinan responden akan keamanan dan manfaat produk. Hasil proses evaluasi alternatif dapat dilihat pada Tabel 5.

Tabel 5.

\section{Hasil Tahap Evaluasi Alternatif}

\begin{tabular}{|c|c|c|}
\hline Evaluasi Alternatif & Keterangan & Jumlah (\%) \\
\hline \multirow[t]{5}{*}{ Dasar perimbangan memilih kosmetik } & Jaminan halal & 46 \\
\hline & Merek & 24 \\
\hline & Harga & 16 \\
\hline & Pilihan varian & 10 \\
\hline & Lainnya & 4 \\
\hline $\begin{array}{ll}\text { Subtotal } \\
\end{array}$ & & 100 \\
\hline \multirow[t]{2}{*}{ Keyakinan keamanan kosmetik berlabel halal } & Ya & 89 \\
\hline & Tidak & 11 \\
\hline Subtotal & & 100 \\
\hline \multirow[t]{2}{*}{ Keyakinan manfaat kosmetik berlabel halal } & Ya & 83 \\
\hline & Tidak & 17 \\
\hline Subtotal & & 100 \\
\hline
\end{tabular}

Sumber : Data diolah (2018) 
Berdasarkan Tabel 5, sebesar $46 \%$ responden menjadikan jaminan halal sebagai dasar memilihi produk kosmetik. Dasar pertimbangan jaminan halaldalam memilih kosmetik tersebut dapat disebabkan oleh tingginya keyakinan responden akan keamanan dan manfaat kosmetik berlabel halal yaitu sebesar $89 \%$ untuk keyakinan keamanan dan $83 \%$ untuk keyakinan akan manfaat yang diperoleh.

\section{Keputusan Pembelian}

Dalam tahap keputusan pembelian, responden melakukan pembelian produk yang menurut mereka paling dibutuhkan. Dalam penelitian ini keputusan pembelian terdiri atas tempat pembelian serta alasan pemilihan, dan jenis pembelian yang dilakukan. Hasil proses keputusan pembelian dapat dilihat pada Tabel 6.

Tabel 6.

\section{Hasil Tahap Keputusan Pembelian}

\begin{tabular}{|c|c|c|}
\hline Keputusan Pembelian & Keterangan & Jumlah (\%) \\
\hline \multirow[t]{5}{*}{ Tempat pembelian kosmetik } & Toko khusus kosmetik & 46 \\
\hline & Supermarket & 36 \\
\hline & Convenience store & 11 \\
\hline & Online shop & 5 \\
\hline & Lainnya & 2 \\
\hline \multicolumn{2}{|c|}{$\begin{array}{ll} & \text { Subtotal } \\
\end{array}$} & 100 \\
\hline \multirow[t]{5}{*}{ Alasan pemilihan tempat pembelian } & Nyaman dan praktis & 42 \\
\hline & Dekat dengan tempat tinggal & 28 \\
\hline & Harga lebih murah & 24 \\
\hline & Pelayanan memuaskan & 5 \\
\hline & Lebih lengkap & 1 \\
\hline \multicolumn{2}{|c|}{ Subtotal } & 100 \\
\hline \multirow[t]{2}{*}{ Jenis pembelian } & Terencana & 58 \\
\hline & Tidak terencana & 42 \\
\hline \multicolumn{2}{|c|}{ Subtotal } & 100 \\
\hline
\end{tabular}

Sumber : Data diolah (2018)

Berdasarkan Tabel 6, sebanyak 46 responden membeli produk kosmetik pada toko khusus kosmetik. Pemilihan tersebut dikarenakan sebagian besar responden merasa tempat tersebut nyaman dan praktis. Jenis pembelian yang dilakukan oleh responden adalah pembelian secara terencana, responden terlebih dulu menentukan produk pilihannya sebelum melakukan pembelian.

\section{Perilaku Pascapembelian}

Setelah melakukan pembelian, jika kinerja produk memenuhi harapan, responden puas. Jika kinerja produk tidak memenuhi kriteria, maka responden akan kecewa. Kedua hal ini lah yang akan menentukan responden untuk melakukan pembelian ulang atau tidak. Dalam penelitian ini, tahap perilaku pascapembelian meliputi kepuasan responden, tindakan saat produk habis, dan tindakan jika harga naik. Hasil tahap perilaku pascapembelian dapat dilihat pada Tabel 7. 
Tabel 7.

Hasil Tahap Perilaku Pascapembelian

\begin{tabular}{|c|c|c|}
\hline Keputusan Pembelian & Keterangan & Jumlah (\%) \\
\hline \multirow[t]{2}{*}{ Kepuasan responden setelah membeli } & Puas & 95 \\
\hline & Tidak puas & 5 \\
\hline \multicolumn{2}{|l|}{ Subtotal } & 100 \\
\hline \multirow[t]{3}{*}{ Tindakan saat produk habis } & Mencari ke toko lain & 63 \\
\hline & Membeli produk sejenis & 19 \\
\hline & Tidak jadi membeli & 18 \\
\hline \multicolumn{2}{|l|}{ Subtotal } & 100 \\
\hline \multirow[t]{2}{*}{ Tindakan jika harga kosmetik naik } & Tetap membeli & 78 \\
\hline & Membeli produk lain & 22 \\
\hline \multicolumn{2}{|l|}{ Subtotal } & 100 \\
\hline
\end{tabular}

Sumber : Data diolah (2018)

Berdasarkan Tabel 7, hampir semua responden yaitu sebanyak 95 responden merasa puas dengan produk kosmetik yang telah dibeli. Tindakan responden saat produk yang akan dibeli habis sebanyak 63 responden akan mencari ke toko lain, serta akan tetap membeli walaupun harga naik. Kedua hal tersebut dapat menggambarkan loyalitas responden terhadap produk kosmetik berlabel halal yang digunakan cukup tinggi. Akan tetapi, walaupun setelah pembelian sebagian besar menyatakan puas, tetapi saat terjadi kenaikan harga, ada beberapa konsumen yang beralih ke produk sejenis lainnya.

\section{Analisis Faktor-Faktor Keputusan Pembelian Kosmetik Berlabel Halal}

Analisis faktor pada penelitian ini dilakukan terhadap 16 variabel, yaitu 1) tren, 2) prestige/gengsi, 3) teman, 4) keluarga, 5) status, 6) usia, 7) pekerjaan, 8) pengeluaran, 9) gaya hidup, 10) keyakinan, 11) pengetahuan, 12) kebutuhan, 13) citra produk, 14) pengalaman, 15) kepercayaan. Pengolahan data awal pada analisis faktor adalah dengan memasukkan 16 variabel yang menghasilkan angka Kaiser-Meyer-Olkin (KMO) dan Measure of Sampling Adequacy (MSA) yang digunakan untuk mengetahui variabel-variabel layak untuk dimasukkan dalam analisis selanjutnya. Selanjutnya nilai Bartlett's Test of Sphrecity menunjukkan signifikansi, berarti matrik korelasi memiliki korelasi signifikan dengan sejumlah variabel. Hasil KMO-MSA yang didapatkan yaitu sebesar 0.897, nilai tersebut lebih besar dari 0.5, maka variabel-variabel tersebut layak untuk dianalisis lebih lanjut. Nilai Bartlett's Test of Sphrecity yang dinyatakan dalam Chi-Square memiliki signifikansi sebesar 0.000 yang berarti mendukung kesimpulan KMOMSA.

Analisis selanjutnya adalah metode ekstraksi untuk membentuk beberapa faktor dengan menggunakan metode Principle Component Analysis. Proses ini menghasilkan nilai communalities. Nilai communalities dapat dilihat pada Tabel 8. 
Tabel 8.

Nilai Communalites

\begin{tabular}{lcc}
\hline No $\quad$ Variabel & Initial & Extraction \\
\hline 1 Tren & 1,000 & 0,75 \\
2 Prestige/gengsi & 1,000 & 0,69 \\
3 Teman & 1,000 & 0,62 \\
4 Saran keluarga & 1,000 & 0,51 \\
5 Status pekerjaan & 1,000 & 0,67 \\
6 Usia & 1,000 & 0,65 \\
7 Jenis pekerjaan & 1,000 & 0,71 \\
8 Pengeluaran & 1,000 & 0,64 \\
9 Gaya hidup & 1,000 & 0,57 \\
10 Keyakinan & 1,000 & 0,88 \\
11 Pengetahuan & 1,000 & 0,87 \\
12 Kebutuhan & 1,000 & 0,88 \\
13 Citra produk & 1,000 & 0,78 \\
14 Pengalaman & 1,000 & 0,79 \\
15 Kepercayaan & 1,000 & 0,83 \\
16 Kebiasaan & 1,000 & 0,74 \\
\hline Sumber : Hasil olah data (SPSS)
\end{tabular}

Keseluruhan nilai dalam tabel communalities menghasilkan nilai lebih dari 0.5. Dapat diartikan bahwa keseluruhan variabel yang digunakan memiliki hubungan yang kuat dengan faktor yang terbentuk. Selanjutnya, dengan melihat Total Variance Explained, hasil menunjukkan jumlah faktor yang terbentuk dari seluruh variabel. Faktor yang mempunyai nilai eigen lebih dari 1 akan dipertahankan dan faktor yang mempunyai nilai eigen kurang dari 1 tidak akan diikutsertakan dalam model. Berdasarkan hasil tersebut jumlah faktor ideal adalah tiga faktor.

Tabel 9.

Nilai Total Variance Explained

\begin{tabular}{|c|c|c|c|c|c|c|c|c|c|}
\hline \multirow[b]{2}{*}{ Comp } & \multicolumn{3}{|c|}{ Initial Eigenvalues } & \multicolumn{3}{|c|}{$\begin{array}{c}\text { Extraction Sums of Squared } \\
\text { Loadings }\end{array}$} & \multicolumn{3}{|c|}{$\begin{array}{c}\text { Rotation Sums of Squared } \\
\text { Loadings }\end{array}$} \\
\hline & Total & $\begin{array}{c}\% \text { of } \\
\text { Variance }\end{array}$ & $\begin{array}{c}\text { Cumulative } \\
\%\end{array}$ & Total & $\begin{array}{c}\% \text { of } \\
\text { Variance }\end{array}$ & $\begin{array}{c}\text { Cumulative } \\
\%\end{array}$ & Total & $\begin{array}{c}\% \text { of } \\
\text { Variance }\end{array}$ & $\begin{array}{c}\text { Cumulative } \\
\%\end{array}$ \\
\hline 1 & 8,073 & 50,456 & 50,456 & 8,073 & 50,456 & 50,456 & 5,837 & 36,479 & 36,479 \\
\hline 2 & 2,404 & 15,026 & 65,482 & 2,404 & 15,026 & 65,482 & 3,378 & 21,114 & 57,593 \\
\hline 3 & 1,106 & 6,915 & 72,396 & 1,106 & 6,915 & 72,396 & 2,369 & 14,803 & 72,396 \\
\hline
\end{tabular}

Selanjutnya dilakukan penentuan nilai factor loading untuk menentukan pengelompokan variabel ke dalam faktor yang sesuai. Nilai factor loading sebesar atau sama dengan 0.50 telah dianggap layak. Berikut ini adalah pengelompokan variabel-variabel awal ke dalam 3 faktor yang telah terbentuk. Kelompok faktor yang terbentuk dapat dilihat pada Tabel 10 . 
Tabel 10.

Kelompok Faktor yang Terbentuk

\begin{tabular}{clccc}
\hline No & Variabel & $\begin{array}{c}\text { Factor } \\
\text { loadings }\end{array}$ & $\begin{array}{c}\text { Kelompok } \\
\text { faktor lama }\end{array}$ & $\begin{array}{c}\text { Kelompok } \\
\text { faktor baru }\end{array}$ \\
\hline 1 & Keyakinan & 0,89 & Pribadi & \\
2 & Pengetahuan & 0,89 & Pribadi & \\
3 & Kebutuhan & $\mathbf{0 , 9 0}$ & Psikologis & \\
4 & Citra produk & 0,83 & Psikologis & Individu \\
5 & Pengalaman & 0,81 & Psikologis & \\
6 & Kepercayaan & 0,89 & Psikologis & \\
7 & Kebiasaan & 0,82 & Psikologis & \\
\hline 8 & Saran keluarga & 0,67 & Sosial & \\
9 & Status pekerjaan & 0,74 & Sosial & \\
10 & Usia & $\mathbf{0 , 7 6}$ & Pribadi & Konsep diri \\
11 & Jenis pekerjaan & 0,74 & Pribadi & \\
12 & Pengeluaran & 0,52 & Pribadi & \\
13 & Gaya hidup & 0,59 & Pribadi & \\
\hline 14 & Tren & $\mathbf{0 , 8 4}$ & Budaya & \\
15 & Prestige/gengsi & 0,79 & Budaya & Sosial Budaya \\
16 & Teman & 0,74 & Sosial & \\
\hline Sumber : Sumber : Hasil olah data (SPSS) & \\
Keterangan : cetak tebal factor loading tertinggi &
\end{tabular}

Berdasarkan Tabel 10, maka terdapat tiga faktor baru yang terbentuk, tiga faktor tersebut adalah sebagai berikut :

\section{Faktor Individu}

Berdasarkan hasil analisis faktor, faktor pertama yang terbentuk diberi nama faktor individu, memiliki tujuh variabel yaitu keyakinan, pengetahuan, kebutuhan, citra produk, pengalaman, kepercayaan, dan kebiasaan. Faktor individu merupakan faktor terbesar yang terbentuk dari analisis faktor karena memiliki keragaman data sebesar 50,46\%, yang berarti proses pengambilan keputusan responden dalam membeli produk kosmetik berlabel halal mempertimbangkan faktor individu dan menjadikannya sebagai faktor yang paling utama dalam memutuskan untuk melakukan pembelian. Variabel kebutuhan memiliki nilai factor loding tertinggi sebesar 0.90 yang menunjukkan bahwa kebutuhan responden akan penggunaan produk halal mendorong responden untuk melakukan pembelian.

\section{Faktor Konsep Diri}

Berdasarkan Tabel 10, faktor kedua yang terbentuk dari analisis faktor diberi nama faktor konsep diri, memiliki enam variabel, yaitu saran keluarga, status pekerjaan, usia, jenis pekerjaan, pengeluaran, dan gaya hidup. Faktor ini memiliki kergaman data sebesar $15,03 \%$. Usia memiliki nilai factor loading tertinggi sebesar 0,76. Usia responden mendorong mereka untuk melakukan pembelian kosmetik berlabel halal. Sebagian besar responden berusia muda dan bekerja sebagai pegawai swasta dimana mereka diharuskan untuk selalu menjaga penampilan, salah satunya dengan menggunakan kosmetik. 


\section{Faktor Sosial Budaya}

Berdasarkan Tabel 10, faktor ketiga yang terbentuk dari analisis faktor diberi nama faktor sosial budaya, memiliki tiga variabel, yaitu tren, prestige/gengsi, dan teman. Faktor ini memiliki keragaman data sebesar 6,92\%. Variabel tren memiliki nilai factor loading tertinggi sebesar 0,84. Adanya tren kosmetik halal yang semakin meningkat menyebabkan responden tertarik untuk mencoba sehingga mendorong mereka untuk akhirnya melakukan pembelian produk-produk kosmetik berlabel halal.

\section{Hasil Analisis Crosstab dengan Uji Chi-square}

Hubungan antara karakteristik responden dengan faktor-faktor yang keputusan pembelian dapat dilihat menggunakan Analisis Crosstab dengan Uji Chi-square. Karakteristik responden dalam hal ini ada 6 variabel yaitu usia, pendidikan, pekerjaan, pendapatan, pengeluaran rata-rata untuk kosmetik dan frekuensi pembelian. Sedangkan faktor-faktor keputusan pembelian responden terdiri dari 4 faktor yaitu budaya, sosial, pribadi, dan psikologis. Hipotesis yang digunakan adalah:

$\mathrm{H}_{0}$ : Tidak ada hubungan antara karakteristik responden dengan faktor-faktor keputusan pembelian kosmetik berlabel halal

$\mathrm{H}_{1}$ : Ada hubungan antara karakteristik responden dengan faktor-faktor keputusan pembelian kosmetik berlabel halal

Berdasarkan hasil analisis Crosstab didapatkan bahwa karakteristik responden secara keseluruhan tidak memiliki hubungan dengan faktor-faktor keputusan pembelian responden, namun ada dua variabel yang mempunyai hubungan yang cukup signifikan dengan nilai Asymp.Sig (2-sided) Chi-square $<\alpha$ $(0,05)$ yaitu variabel frekuensi pembelian dengan faktor budaya dan frekuensi pembelian dengan faktor sosial. Hasil dari uji Chi-square dari variabel frekuensi dengan faktor budaya dapat dilihat pada Tabel 11.

Tabel 11.

Hasil Uji Chi-Square Karakteristik Responden terhadap Faktor Keputusan Pembelian

\begin{tabular}{|c|c|c|c|}
\hline \multicolumn{4}{|c|}{ Hasil Uji Chi-square terhadap variabel frekuensi dengan faktor budaya } \\
\hline & Value & df & Asymp.Sig (2-sided) \\
\hline Pearson Chi-square & $27,98^{\mathrm{a}}$ & 16 & 032 \\
\hline Likelihood Ratio & 32,80 & 16 & 01 \\
\hline Linear-by-Linear Asosiation & 7,40 & 1 & 01 \\
\hline $\mathrm{N}$ of Valid Cases & 100 & & \\
\hline \multicolumn{4}{|c|}{ Hasil uji Chi-square terhadap variabel frekuensi dengan faktor sosial } \\
\hline & Value & Df & Asymp.Sig (2-sided) \\
\hline Pearson Chi-square & $34,82^{\mathrm{a}}$ & 16 & ,004 \\
\hline Likelihood Ratio & 42,49 & 16 & ,000 \\
\hline Linear-by-Linear Asosiation & 9,01 & 1 & 003 \\
\hline $\mathrm{N}$ of Valid Cases & 100 & & \\
\hline
\end{tabular}

Sumber : Sumber : Hasil olah data (SPSS) 


\section{Hasil Net Promoter Score (NPS)}

Setelah melakukan pembelian dan melakukan evaluasi terhadap produk kosmetik berlabel halal, responden memiliki kemungkinan untuk merekomendasikan produknya kepada orag lain. Oleh karena itu, dalam penelitian ini digunakan nilai NPS untuk mengetahui apakah responden yang merekomendasikan lebih banyak atau lebih sedikit terhadap responden yang tidak mau merekomendasikan. Jawaban responden yang telah terbagi menjadi 3 kategori, dapat dilihat pada Tabel 12 berikut.

Tabel 12.

Hasil Net Promoter Score (NPS)

\begin{tabular}{clcr}
\hline No & Kategori & Jumlah Responden \\
\hline 1 & Promoter & 46 & \\
2 & Passive & 45 & \\
3 & Detractor & 9 & 100 \\
\hline \multicolumn{4}{c}{ Total }
\end{tabular}

Berdasarkan Tabel 12, terdapat 9 orang responden dengan kategori detractor, 45 responden kategori passive, dan 46 responden dengan kategori promoter, sehingga nilai NPS adalah sebagai berikut:

$$
\begin{aligned}
\text { Net Promoter Score } & =\% \text { Promoters - \% Detractors } \\
& =46 \%-9 \% \\
& =37 \%
\end{aligned}
$$

Didapatkan nilai NPS terhadap kosmetik berlabel halal sebesar 37\%, yang berarti lebih banyak responden yang merekoemndasikan kosmetik berlabel halal dibandingkan responden yang tidak mau merekomendasikan.

\section{E. SIMPULAN}

Hasil penelitian yang dilakukan mengenai faktor keputusan pembelian kosmetik berlabel halal di Kota Bogor adalah:

1. Karakteristik responden adalah wanita karir yang berdomisili di Kota Bogor, berusia muda atau fresh graduated, dengan pendidikan mayoritas diploma, bekerja sebagai pegawai swasta, rentang pendapatan kelas menengah, pengeluaran rata-rata untuk kosmetik seratus lima puluh ribu rupiah dengan frekuensi pembelian kosmetik sebanyak empat hingga enam kali per tahun.

2. Proses pengambilan keputusan pembelian terjadi melalui lima tahap. Pada tahap pengenalan yang paling berpengaruh adalah mutu produk, pengaruh teman, dan pengaruh harga. Pada tahap pecarian informasi yang perlu diperhatikan adalah komposisi produk dan sumber informasi komersial. Pada tahap evaluasi alternatif yang perlu diperhatikan adalah jaminan akan keamanan dan manfaat produk kosmetik berlabel halal. Jawaban dominan pada tahap keputusan pembelian adalah kenyamanan dan kepraktisan tempat 
pembelian. Pada tahap periaku pascapembelian yang mempengaruhi responden untuk melakukan pembelian adalah kepuasan responden dan pemberian harga pada produk kosmetik.

3. Faktor-faktor yang membentuk keputusan pembelian kosmetik berlabel halal ada tiga faktor yaitu faktor individu, faktor konsep diri, dan faktor sosial-budaya. Faktor dominan dalam pengambilan keputusan pembelian adalah faktor individu, dengan variabel yang paling berhubungan adalah kebutuhan responden akan penggunaan produk halal. 


\section{DAFTAR PUSTAKA}

BIZTEKA.(2015). PerkembanganPasarIndustriKosmetik Di Indonesia, 2010 2015[Internet].Diakses 13 Oktober 2017. Tersedia pada :http://cciindonesia.com/2016/06/17/perkembangan-pasarindustri-kosmetik-diindonesia-2010-2015

[BPOM] Badan Pengawas Obat dan Makanan. (2011). Metode Analisis Kosmetika. Jakarta : BPOM

[CMCCS] Center fo Middle-Class Consumer Study. (2013): Uncovering the Aspirations, Values, and Behaviors[Internet]. Diakses pada 20 Februari 2018. Tersedia pada: https://swa.co.id/swa/announcement/indonesia-middleclass-consumer-report-2013-uncovering-the-aspirations-values-and$\underline{\text { behaviors }}$

Engel, J.F, Blackwell, R.D, dan Miniard, P.W. (2011). Perilaku Konsumen. Jakarta : Binarupa Aksara

Kotler, P dan Armstrong, G. (2008). Prinsip-Prinsip Pemasaran Edisi Kedua Belas. Jakarta : Penerbit Erlangga

Kotler, P dan Keller, K.L. (2009). Manajemen Pemasaran Edisi Ketiga Belas. Jakarta : PT Indeks

[LPPOMMUI] Lembaga Pengkajian Pangan, Obat-obatan dan Kosmetika Majelis Ulama Indonesia. (2017). Certification. Tersedia pada http://elppommui.org/ certification

Reichheld, F. (2011). The Ultimate Question : How Net Promoter Companies Thrive in a Customer-Driven World. Boston : Harvard Business School Publishing

Riduwan,S. (2011). Pengantar Statistika untuk Penelitian Pendidikan, Sosial, Ekonomi dan Bisnis. Bandung : Alfabeta

Schiffman, L dan Kanuk, LL. (2011). Consumer Behavior. London : Pearson Education

Simamora, B. (2005). Analisis Multivariat Pemasaran. Jakarta : Gramedia Pustaka Utama

Tirto. (2016). Kala Kosmetik Lokal Jadi Jawara Pasar [Internet]. Di akses pada 19 Oktober 2017. Tersedia pada : https://tirto.id/kala-kosmetik-halal-jadijawara-pasar-brVB

Wahyono, T. (2006). ANDAS dengan SPSS 14. Jakarta : PT Elex Media Komputindo

Widarjono, A. (2015). Analisis Statistika Multivariat Terapan. Yogyakarta : UPP STIM YKPN 